\title{
Conceptualization of the Kazakh language in the Linguistic Consciousness of the Kazakhs
}

\author{
Gulzhana Jenalayeva ${ }^{1}$ 8(D) $\triangle$, Gaukhar Niyar ${ }^{2}$ 8(D) and Moldir Zhubanyshbayeva ${ }^{3}$ (iD \\ ${ }^{1}$ PhD, Associate Professor, the Department of Languages, West Kazakhstan Marat Ospanov Medical University; the Department \\ of the English and German languages, K. Zhubanov Aktobe Regional University, Aktobe city, the Republic of Kazakhstan \\ ${ }^{23}$ First-year MSc students, the Department of the English and German Languages, K. Zhubanov Aktobe Regional University, \\ Aktobe city, the Republic of Kazakhstan
}

$\triangle$ Corresponding Author: Gulzhana Jenalayeva, E-mail: kuzembayeva@mail.ru

\section{ARTICLE INFORMATION}

Received: March 01, 2021

Accepted: April 22, 2021

Volume: 3

Issue: 4

DOI: $10.32996 /$ jhsss.2021.3.4.8

\section{KEYWORDS}

Psycholinguistic study, semantic field, associative experiment, proverbs, cognitive analysis, concept, linguistic consciousness, ethno-specificity, linguoculture, the Kazakh language

\section{ABSTRACT}

The purpose of this study is to describe ways of conceptualizing the Kazakh language from the perspectives of the representatives of the Kazakh nation. Language is a very important phenomenon for the people, which reflects their national characteristics. Of great interest is the conceptualization of the Kazakh language by representatives of the Kazakh linguoculture in the context of the situation when public opinion recognizes its position in general and its status as unsatisfactory rather than satisfactory. A special contribution of the author to the study of the topic is to conduct a free-associative experiment among native speakers of the Kazakh language on the stimulus-word "қазақ тілі". The novelty of the study lies in the fact that the obtained associative data were distributed according to the frequency criterion with subsequent modeling of the associative field and its cognitive structure. A free associative experiment was carried out among the native speakers of the Kazakh language. The results of the study demonstrate that the Kazakh language reflects the origins of the nation, its history and customs. The native language for the Kazakh ethnic group is associated with Motherland, pride and patriotism. Analysis of proverbs, sayings and literary contexts have shown that the Kazakh language is very rich and actualizes the beginning of upbringing and morality.

\section{Introduction}

The central topics of inquiry in modern linguistics (such as psycholinguistics, cultural linguistics, and sociolinguistics) are linguistic consciousness and the image of the world (Kuzembayeva et al., 2019: 30). They cover studies of units of language and linguistic structures, in which their psychologically real content is revealed, that is, in what real, "psychologically authentic" set of semantic components a certain meaning exists in the consciousness of an ethnos and is stored in its linguistic memory; how the separate meaningful components which make up a word semantics are related in terms of "brightness" and relevance, what real semantic connections of words and structures are in the language memory of a person (Popova \& Sternin, 2001). Psycholinguistic meaning is usually broader and more voluminous than its lexicographic correlate (which, as a rule, is entirely included in the psycholinguistic meaning, although its components may occupy different places in the psycholinguistic meaning in terms of brightness) (Sternin \& Rudakova, 2011). In this respect, Russian psycholinguists have used the associative method to investigate the so-called cultural specificity of linguistic consciousness (Pax et al, 2019: 11). The method of associative experiment based on verbal associations of subjects participating in the investigation is considered to be effective since it reveals the peculiarities of the national, linguistic awareness of people, i.e. connections of words in their consciousness, their semantic and hierarchical subordination, the brightness of certain components of the meaning of the stimulus word, their axiological features in the society (Mukhametzyanova \& Shayakhmetova, 2014). Moreover, it allows revealing mental images of the external world inherent in representatives of a certain ethnic group (Kuzembayeva et al, 2019: 31).

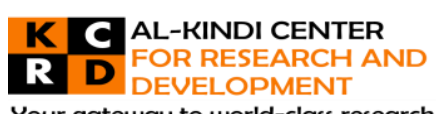

Your gateway to world-class research

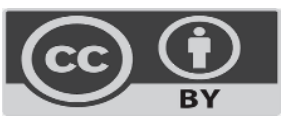

Published by Al-Kindi Center for Research and Development. Copyright (c) the author(s). This open access article is distributed under a Creative Commons Attribution (CC-BY) 4.0 license 
Thus, the data obtained by means of a free associative experiment can be interpreted as a consciousness reflection of representatives from different cultures and will reveal characteristics of linguistic consciousness and the national and cultural specificity of a particular ethnos.

The aim of the study is to describe ways of conceptualizing native language by representatives of the Kazakh ethnos, modeling the associative field "қазақ тілі" (the Kazakh language) in the Kazakh linguistic culture, and identifying peculiarities in the conceptualization of the native language among speakers of the Kazakh language. The importance of the study is justified as the chosen concept қазақ тілі, being the micromodel of the national cognitive mentality, serves as a tool for revealing national specifics in the minds of native speakers of a given ethnic group. A nation is often associated with its language, a very important phenomenon for the people, which reflects their national characteristics. On the one hand, it serves as one of the constants that exist in the minds of native speakers of the Kazakh language; on the other hand, it is characterized by quite rich multilateral features in terms of its content.

\section{Linguistic analysis of the concept the Kazakh Language}

Attempts to probe into the concept of Russian and other languages have been repeatedly made in national science (Shushakova, 2012; Tavgiridze, 2005; Musina, 2008), but no studies were conducted on the concept of the Kazakh language.

In the Dictionary of the Kazakh Literary Language (2011) the lexeme "қазақ тілі" has the following meanings: 1) түркі тілдерінің қыпшақ тобына жататын әдеби тілі бай ауыз әдебиетінің жалпыхалықтық тілдің негізінде қалыптасқан қазіргі қазақ халқының ұлттық тілі, Қазақстан Республикасының мемлекеттік тілі (literary language belonging to the Kipchak group of Turkic languages is the national language of modern Kazakh people formed based on the popular language of oral literature, the state language of the Republic of Kazakhstan (translated by authors);

2) қазақ халқының құрамына енген ру-тайпалар тілдерінің негізінде XIV - XV ғасырларда қалыптасып, біртұтас халықтық тілге айналған, бұл күнде туыстас түркі тілдерінің ішінде ең бай әрі дамыған ұлт тілдерінің бірі; өзінің кейбір жергілікті ерекшеліктеріне қарамастан тұтастығын толық сақтап қалған жалпыхалықтық тіл, қазақ ұлтының жан - жақты дамыған ұлт ең бай тық тілі; белгілі нормаға түскен, жазу дәстүріне ие, стильдік жүйесі қалыптасқан әдеби тіл (language of the tribes that became part of the Kazakh people was formed in XIV-XV centuries and became a single national language, on this day, one of the richest and most developed national languages among related Turkic languages; national language, fully retaining its integrity, despite some local; a literary language that has entered a certain norm, has a tradition of writing, a style system (translated by authors). From the analysis of the dictionary definition, we can assume that the Kazakh language, based on the tribal languages that became part of the Kazakh people, was formed in the XIV-XV centuries and became a single folk language, one of the richest and most developed languages of the Turkic peoples today.

Proverbs, being a special type of linguistic and cultural text characterized by markers of the community, value-semantic, associative and expressive content, reflect national cultural information differently. They include specific and familiar images, which in the process of use and rethinking acquire a deep generalization. In ethnocultural metaphors, there are ideas about a man, about his life, experiences, relationships - everything that determines the ethnocultural existence of the people, his mentality (Orlova et al, 2018). Proverbs are an important part of the Kazakh vocabulary and lexicology. They reflect social concepts, cultural system, and value orientation of the Kazakh people. In the course of the study of the Kazakh proverbs, the relation of the Kazakh people towards their native language was revealed. The Kazakhs consider their language as wealth: Қазақ тілі - өлшеусіз қазына, өрісі кең әлем / The Kazakh language is an immense treasure, an immense world (translated by the authors).

the language that has great potential: Қазақ тілі - ел басқарудың құралы / The Kazakh language is a tool for managing the country (translated by the authors). This is confirmed by the following examples from the Kazakh literary contexts: Ұлmтың тілі кеми бастауы ұлттың құри бастағанын көрсетеді. Ұлтқа тілінен қымбат нәрсе болмасқа тиісті. Бір ұлттың тілінде сол ұлттың сыры, тарихы, тұрмысы, мінезі айнадай көрініп тұрады. Қазақ тілінде қазақтың сары сайран даласы, біресе желсіз түндей тымық, біресе құйындай екпінді тарихы, сар далада үдере көшкен тұрмысы, асықпайтын, саспайтын сабырлы мінезі - бәрі көрініп тұр. (Мағжан Жұмабаев "Педагогика", 1126) / The collapse of the national language indicates the beginning of the collapse of the nation. It is not necessary for a nation to have anything more expensive than a language. The language, history, way of life and character of these people are reflected in the language of the nation. In the Kazakh language, the history of the Kazakh steppe, the history of a restless night, whirlwind, life in the steppe, calm and restless nature everything is visible (translated by the authors). In this example, through the Kazakh language, we can see the specifics of the history and life of the Kazakh people. The language is closely linked to the history of its people. First, the language tells us about the historical changes and progress that our native country has experienced. It is this means of communication that reflects the development of a particular nation. Knowing the transformations that have taken place in it, we join the historical heritage of our country: Қазақ өз елінде ұлтmық азшылыққа айналды, ана тілі, Отан тарихы тығырыққа тірелді, ұлы державалық 
шовинизм қоздады, орыстандыру белең алды, жеріміз экологиялық апатқа ұшырады (М. Қозыбаев, Өркениет және ұлт) / A Kazakh has become a national minority in his country, his native language, the history of the Motherland have become deadlocked, great power chauvinism has been shaken, Russification has begun, and our land has fallen into an environmental disaster (translated by the authors).

Respect for the native language is equivalent to respect for the country because the language is sacred for every person: Tiлiн білмейтіндер емес, тілін білгісі келмейтіндер - мәңгүрт. / Not those who do not know the language, but those who do not want to know the language are foolish (translated by the authors).

Prominent Kazakh writers dreamt that one day the Kazakh language would take an important role among the Turkic world: Күндерде бір күн түрік балаларының тілі біріксе, ол біріккен тілдің негізі қазақ тілі болса, сөз жоқ, түрік елінің келешек тарихында қазақ ұлты төрден орын алмақшы (М. Жұмабаев "Педагогика", 116б) / If one day the language of the Turkic children unites, and the Kazakh language becomes the basis of a single language, of course, in the future history of the Turkic people, the Kazakh people will take its respected place (translated by the authors).

The Kazakh language is rich. It covers a wide range of science, industry, social and political life: Осының өзі-ақ, қазақ тілінің жетілген беллетристика тілі ғана емес, толыққанды саяси және ғылыми публицистиканың тілі екендігіне көзімізді анық жеткізе түседі (Ә. Кекілбаев, Үи белес) / This clearly shows that the Kazakh language is not only the language of advanced fiction but also the language of full-fledged political and scientific journalism (translated by the authors).

Looking at it, the Kazakh language proves that it is a language that can convey a simple story to the reader: Тіл сөйлеy сөйлесу, оқу-үйрену, жазу-сызу арқылы өседі. Бұл үшеуінің бірде-біріне көңіл аудармау ең үлкен қылмыс. Этика, эстетика дегендердің тым нәзік сырларын әр халық өз тілінде ғана еркін түсінсе керек_(Ғ. Мүсірепов Таңдамалы шығармалар, 542 б) / The language grows by speaking, reading and learning, writing and drawing. Not paying attention to any of these components is the biggest crime. It should be noted that every nation can freely understand the subtleties of ethics and aesthetics only in its language (translated by the authors). Every nation has its native language inherited from our ancestors. We see the importance of the mother tongue. Kazakh is one of the most developed, mature, rich, and flexible languages. This is the image of the people, the nation, the blood of our ancestors. But even though Kazakhstan is an independent country, the representatives of the Kazakh nation cannot achieve significant success in terms of speaking the native language. The language problem in modern Kazakh society starts with ignorance towards the language. The creator and developer of the language are the people themselves. There is no future for a nation that does not preserve its native language: Ана тілі дегеніміз - сол тілді жасаған, жасап келе жатқан халықтың, баяғысын да, бүгінгісін де, болашағын да танытатын, сол халықтың мәңгілігінің мәңгілік мәселесі. Ана тілін тек өгей ұлдары ғана менсінбейді,өгей ұлдары ғана аяққа басады (Ғ. Мүсірепов Таңдамалы шығармалар, 542 б) / The native language is the eternal problem of the eternity of people who created and continue to create this language, both in the past and in the present and the future (translated by the authors).

In the Kazakh family, when the child begins to speak clearly, special attention is paid to the correct expression of kinship terms, family genealogy, and people of the country. Our ancestors believed that knowledge of the history of origin contributes to forming the civil and patriotic qualities in a child. So language is the beginning of upbringing: Тәрбие тілден басталады / Upbringing begins with language (translated by the authors); Әдеn пен адамгершілік ана тіліңнен нәр алады. / Еtiquette and morality are rooted in your native language (translated by the authors). Identity as a nation, a country is preserved when a nation is able to realize it through the language.

Language is the best medium for establishing friendship and harmony. The more languages people learn, the more they know. No language of the world is aimed at destruction, enmity, hatred. The functions of language are communication, cognition, friendship, and consent: Тіл - достықтың алтын көnipi / Language is the golden bridge of friendship (translated by the authors).

Currently, in the context of the Policy of Trilingualism in the Republic of Kazakhstan, speaking one language is not enough. Language learning can take place in a wide variety of situations. For example, colonized countries had to speak two or three languages: Аузы құлып сандықты тіс ашпаса, тіл ашады; Шет елдерге араласа жүріп, халықаралық бір тіл білмеу деген үлкен қорлық. Көпшілігі кешегі күнге дейін отар болған Азия-Африка елдерінде ағылшын, француз тілдері өз тілдеріндей (Ғ. Мүсірепов Таңдамалы шығармалар, 535 б) / Not knowing a single international language while traveling abroad is a great insult. In Asian-African countries, most of which have been colonized before yesterday, English and French are their languages; Өз тілің - бірлік үшін, Өзге тілің - тірлік үшін / Your language is for unity, another language is for life. It is good to know another language, but it is better to respect your language; Әр халықтың ана тілі - білімнің кілті (А. Жұбанов) / Тhe native language of every nation is the key to education. Having analyzed the proverbs and sayings, we can assume that the Kazakh language is considered the most important cultural value of the nation. By its means, knowledge is passed from one to another

Page | 69 
and preserved for future generations. It is necessary to preserve the native language to keep to the national culture and traditions.

\section{Methodology}

The free associative experiment, being one of the ways to identify the associative fields of cultural and national images represented in the language picture of the world, was used in our study.

Students from K. Zhubanov Aktobe Regional University and West Kazakhstan Marat Ospanov Medical University (Aktobe, the Republic of Kazakhstan) took part in the free-associative experiment. The respondents comply with people from Uralsk, Atyrau, Aktau, Kyzylorda, and Aktobe cities studying at the universities mentioned above. The total number of respondents is 219 people aged 17-23 years, of which 86 respondents are males and 133 are females. The stimulus "қазақ тілі" was offered and the respondents issued in writing the first associations with it that came to mind. The number of reactions was not limited.

Data obtained from a free associative experiment was comprehensively analyzed by defining the frequency ratio of reactions, i.e. lexical associations, and determining the core-periphery relationship between them. By cognitive analysis of the associative field "қазақ тілі" in the Kazakh language, semantic zones in its structure were distinguished.

\section{Results and Discussion}

In the course of the free-associative experiment, 746 associative reactions were received, of which 47 were different. Based on the frequency of lexical associations, the core (identified by reactions from more than 40 respondents), the near periphery (20$40)$, the far periphery (10-20), and the outer periphery $(<10)$ were determined (see Table 1$)$.

Table 1: The associative field of the stimulus қазақ тілі in the Kazakh linguistic consciousness

\begin{tabular}{|c|c|}
\hline Core & $\begin{array}{l}\text { ана тілі (mother tongue) 82, Абай (Abay) 47, қазақ ұлты (kazakh nationality) 44, Отан (homeland) 45, } \\
\text { Қазақстан (Kazakhstan) 43, }\end{array}$ \\
\hline Near periphery & $\begin{array}{l}\text { мемлекеттік тіл (state language) 29, дәстүр (tradition) 28, әліпби (alphabet) 25, тарих (history) 23, } \\
\text { тәуелсіздік (independence) 22, әдебиет (literature) 21, патриотизм (patriotism) 21, }\end{array}$ \\
\hline Far periphery & $\begin{array}{l}\text { мақтаныш (pride) 19, құндылық (value) 18, шежіре (genealogy) 17, ақындар (poets) 16, ұлт } \\
\text { (nationality) 16, алаш (alash) 14, тәрбие (upbringing) 14, ата-aна (parents) 12, бай (rich) 13, отбасы } \\
\text { (family) 12, pyx (spirit) 12, Ахмет Байтұрсынов 11, грамматика (grammar) 11, мұра (heritage) 11, түркі } \\
\text { тілдер (turkic languages) 11, болашақ (future) 10, абырой (reputation) 10, ана (mother) 10, }\end{array}$ \\
\hline Outer periphery & $\begin{array}{l}\text { ережелер (rules) 9, кітап (book) 9, шешендік (oratory) 9, қарапайым (simple) 7, латын (latin) 7, } \\
\text { коммуникация (communication) 6, мейірімділік (kindness) 5, Шәкәрім (Shakarim) 5, әдемі (beautiful) } \\
\text { 4, этнос (ethnos) 4, қиын (complicated) 4, Қызылорда (Kyzylorda) 3, саясат (politics) 2, терең (deep) 2, } \\
\text { айтыс (aitys) 1, таза (clear) 1, оралымды (eloquent) 1. }\end{array}$ \\
\hline
\end{tabular}

Source: authors

As a result of the cognitive analysis of the associative field "қазақ тілі" in the Kazakh language the following semantic zones we distinguished, the order of the components was determined by their number. Associations in semantic zones are given in decreasing order of their frequency:

Language (201 - 26.94\%): 'Ана тілі' mother tongue (10.99\%), 'мемлекеттік тіл' state language (3.89\%), 'әліпби' alphabet (3.35\%), 'әдебиет' literature (2.8\%), 'грамматика' grammar (1.5\%), 'түркі тілдер' Turkic languages (1.5\%), 'кітап' book (1.2\%), 'латын' Latin (0.9\%), 'коммуникация' communication (0.8\%);

Nation and country (155 - 20.8\%): 'Отан' homeland (6.03\%), 'қазақ ұлты' Kazakh nationality (5.9\%), 'Қазақстан' Каzakhstan (5.8\%), 'ұлт' nationality (2.14\%) 'Қызылорда' 'этнос' ethnos (0.5\%), Kyzylorda (0.4\%);

History and ideals (132 - 17.73\%): 'тарих' history (3.08\%), 'тәуелсіздік' independence (2.95\%), 'патриотизм' раtriotism (2.82\%), 'шежіре' genealogy (2.28\%), 'Алаш' Alash (1.88\%), 'pyx' spirit (1.6\%), 'мұра' heritage (1.48\%), 'болашақ' future (1.34\%); 'саясат' politics (0.27\%);

Kazakh poets and writers (89 - 11.93\%): 'Абай' Abay (6.3\%), 'ақындар' poets (2.14\%), 'Ахмет Байтұрсынов' Аkhmеt Baitursynov (1.5\%), 'шешендік' oratory (1.2\%), 'Шәкәрім' Shakarim (0.67\%), 'айтыс' aitys (0.13\%);

Axiological notions (79 - 10.59\%): 'мақтаныш' pride (2.55\%), 'құндылық' value (2.41\%), 'бай' rich (1.74\%), 'абырой' reputation (1.34\%), 'қарапайым' simple (0.94\%); 'әдемі' beautiful (0.54\%), 'қиын' complicated (0.54\%), 'терең' deep (0.27\%), 'таза' сlеar (0.13\%), 'оралымды' eloquent (0.13\%);

Norms (51 - 6.84\%): 'дәстүр' tradition (3.75\%), 'тәрбие' upbringing (1.88\%), 'ережелер' rules (1.2\%);

Family (34 - 4.56\%): 'ата-ана' parents (1.6\%), 'отбасы'family (1.6\%), 'ана' mother (1.34\%);

Morals (5 - 0.67\%): 'мейірімділік' kindness (0.67\%). 
Semantic zones that were formed include language (26.94\%), nation and country (20.8\%), history and ideals (17.73\%), Kazakh poets and writers (11.93\%), axiological notions (10.59\%), norms (6.84\%), family (4.56\%), morals $(0.67 \%)$.

It follows from the obtained data that the Kazakh language in the Kazakh linguistic consciousness is objectified, first of all, by the mother tongue (10.99\%), Abay (6.3\%), homeland (6.03\%) and the Kazakh nationality (5.9\%). In addition, the native language, according to the associative reactions of the Kazakh respondents, actualizes Kazakhstan (5.8\%), state language (3.9\%), tradition (3.8\%), alphabet (3.6\%), history (3.1\%), independence (2.95\%), literature (2.8\%) and patriotism (2.8\%).

\section{Conclusion}

This psycholinguistic (free-associative) experiment aimed at describing the concept of the native language in the minds of the Kazakh native speakers is a valuable source of information and an effective tool for determining the content of concepts in the linguistic consciousness of the ethnos. It is also efficient in studying the ethnical specificity of nations, contributing to understanding and successful intercultural interaction between representatives of different linguocultures.

The associative experiment showed that 'the Kazakh language' has an extensive associative field (746 reactions), which proves its importance for the Kazakh linguistic consciousness. The associative field is divided into meaningful zones without the remainder and forms 8 semantic zones: language, nation and country, history and ideals, Kazakh poets and writers, axiological notions, norms, family and morals. These semantic zones characterize various aspects of understanding the Kazakh language by representatives of the Kazakh ethnos. The most voluminous semantic zone in the associative field is the group that includes features of language in general (26.94\%), nation / country (20.8\%) and history / ideals (17.73\%). The most prominent components of this zone is mother tongue (10.99\%), state language (3.89\%), alphabet (3.35\%), literature (2.8\%), homeland (6.03\%), Kazakh nationality (5.9\%), Kazakhstan (5.8\%), history (3.08\%), independence (2.95\%), patriotism (2.82\%).

Thus, the Kazakh language in linguistic consciousness of the native speakers is, in the first place, objectified by the mother tongue which is a state language, Kazakh nation and country, its history, independence and literature. The limitations of the study are connected with the geographic scope of participants. The survey respondents represented the western part of the Republic of Kazakhstan, and the limited ability to gain access to the citizens of other regions might have had its impact on the study results in describing the linguistic consciousness of the Kazakhs in general. We believe that a further comparative research of representatives of different parts of the country and a cross-cultural study of language conceptualizations of other nations has great prospects for scientific research.

\section{References}

[1] Kuzembayeva G. et al. (2019). Nobility in the linguistic consciousness of Russians and Kazakhs. Xlinguae, 12(4), 30-40.

[2] Mukhametzyanova L., Shayakhmetova L. (2014). Application of Associative Experiment in Forming the Foreign Communicative Competence. English Language Teaching, 7(12).

[3] Musina I. I. (2008). Mezhjazykovye osobennosti realizacii variantov konceptov tatarskij jazyk, russkij jazyk, anglijskij jazyk [Interlanguage spesifics of realization of concepts the Tatar, Russian, English languages]. Thesis. Kazan, $19 \mathrm{p}$.

[4] Orlova T.G., Kolosova A.A., Medvedev Ju.S., Barov S.A. (2018). Expressing of national and cultural identity in English and Russian proverbs. Vestnik Rossijskogo universiteta druzhby narodov. Serija: Teorija jazyka. Semiotika. Semantika, Journal of RUDN. Theory of Language. Semiotics. Semantics, 9(2).

[5] Pax L.S., Ufimtseva N.V., Markovina I.J. (2019). Language, consciousness and culture: some suggestions to develop further the Moscow School of Psycholinguistics. Jazyk i kul'tura [Langauge and Culture], 47.

[6] Popova Z. D., Sternin I. A. (2001). Ocherki po kognitivnoj lingvistike [Issues of Cognitive Linguistics]. Voronezh, ISTOKI.

[7] Shushakova O. V. (2012). Koncept «Russkij jazyk» v jazykovom soznanii shkol'nika (k postanovke problemy) [Concept the Russian language in the linguistic consciousness of pupils (stating the problem)]. Vestnik Irkutskogo gosudarstvennogo tehnicheskogo universiteta [Journal of Irkutsk state technical university], No. 6(65).

[8] Sternin I. A., Rudakova A. V. (2011). Psiholingvisticheskoe znachenie slova i ego opisanie [Psycholinguistic meanng of the word and its description]. Voronezh, Lambert.

[9] Tavdgiridze L. A. (2005). Koncept russkij jazyk v russkom jazykovom soznanii [Concept the Russian language in the Russian linguistic consciousness]. Thesis. Voronezh.

[10] Қазақ әdebi tiliniң sөzdigi [Dictionary of the Kazakh literary language] (2011). Eds.: M.Malbaқоv, N.Oңғarbaeva, A.Yderbaev zhəne t.b. Almaty, Vol. 10, K-M, 752 p. 